\title{
PENGARUH PENERAPAN MODEL DISCOVERY LEARNING TERHADAP KEMAMPUAN BERPIKIR KRITIS MUATAN IPA SISWA KELAS IV
}

\author{
Yulita Dwi Aryani $^{1^{*}}$, Wasitohadi ${ }^{2}$ \\ 1,2 Program Studi Pendidikan Guru Sekolah Dasar, Fakultas Keguruan dan Ilmu Pendidikan, \\ Universitas Kristen Satya Wacana, Salatiga, Indonesia
}

Korespondensi. *E-mail: 292016067@student.uksw.edu

\begin{abstract}
Abstrak
Penelitian ini memiliki tujuan yaitu untuk mengetahui pengaruh penerapan model discovery learning terhadap kemampuan berpikir kritis siswa SD. Metode penelitian ini menggunakan eksperimental-semu (Quasi Experimental Design) dengan Pre-test Post-test Non-equivalent Control Group Design dan menggunakan teknik pengambilan sampel purpose sampling. Penelitian ini menggunakan analisis data Uji-t. Penelitian ini dilakukan di SD Negeri Mangunsari 01 Salatiga dan SD Negeri Mangunsari 05 Salatiga Gugus Diponegoro. Dalam penelitian ini, kemampuan berpikir kritis siswa pada muatan IPA pada kelas ekperimen dengan presentase pre test yaitu $67 \%$ dan setelah dilakukan perlakuan model discovery learning nilai post test meningkat menjadi $86 \%$ dan presentase pre test kelas kontrol yaitu $65 \%$ dan post test $83 \%$. Presentase kemampuan berpikir kritis siswa pada kelas eksperimen dengan menggunakan model discovery learning lebih tinggi dibandingkan dengan kelas kontrol yang menggunakan model poblem based learning . Didukung pula dengan uji $\mathrm{T}$ dalam penelitian menggunakan Independent Sample T-Test bahwa nilai signifikasi yaitu $0,000<0,05$ dan $t$ hitung $>t$ tabel yaitu 9,556 2,664 sehingga dapat dinyatakan Ho ditolak dan Ha diterima atau terdapat pengaruh yang signifikan dalam penerapan model discovery learning terhadap kemampuan berpikir kritis siswa SD. Kesimpulan penelitian ini yaitu terdapat pengaruh yang signifikan terhadap kemampuan berpikir kritis siswa kelas IV SD dengan menggunakan model discovery learning.
\end{abstract}

Kata Kunci: Discovery Learning, Kemampuan Berpikir Kritis

\section{THE EFFECT OF APPLYING DISCOVERY LEARNING MODEL TO CRITICAL THINGKING SKILLS ON SCIENCE SUBJECT FOR GRADE 4 STUDENT}

\begin{abstract}
The aim of the research is to get a result the effect of discovery learning model to critical thinking skills of elementary school student. The method of the research used Quasi Experimental Design with Pre-test Post-test Non-equivalent Control Group Design and used purpose sampling technique. Analysis data used Uji-t. The research implemented in SD Negeri Mangunsari 01 Salatiga and SD Negeri Mangunsari 05 Salatiga Gugus Diponegoro. In this research of critical thinking skills of student elementary school on science lesson, the percentage pre test in experimental class $67 \%$ and after applying the discovery learning model the post test is $86 \%$ and percentage pre test in control clas is $65 \%$ and the post test is $83 \%$. The percentage on experimental classwith discovery model is higher than control class with problem based learning model. Uji T with Independent Sample T-Test that significant value is 0,000<0,05 dan $t>t$ table is $9,556>$ 2,664. The means that Ho is refused and Ha is accepted or there ar significant effect in critical thinking skills. The conclusion of the research is there are significant effect in critical thinking skills of student elementary school grade 4 by discovery learning model.
\end{abstract}

Keywords: Discovery Learning, Critical Thinking Skills

Copyright $\mathbb{0} 2020$, JRPD, ISSN 2615 - 1723 (Print), ISSN 2615 - 1766 (Online) 


\section{PENDAHULUAN}

Perkembangan pengetahuan dan teknologi yang kompleks pada abad 21 merupakan tantangan khususnya di dalam dunia pendidikan untuk mempersiapkan sumber daya manusia yang memiliki kualitas, sehingga diperlukan acuan kurikulum dalam pembelajaran di sekolah untuk mendorong dan mengembangkan kemampuan dari siswa.

Kurikulum 2013 merupakan acuan kurikulum pendidikan nasional yang memiliki karakteristik dalam mengembangkan tiga ranah antara lain ranah sikap, spiritual, dan sosial (afektif), pengetahuan (kognitif), dan ketrampilan (psikomotorik) tidak hanya memuat materi pelajaran yang bersifat pemahaman dan hafalan namun terdiri atas materi yang lebih kompleks serta memerlukan proses aplikasi, analisis serta evaluasi untuk menciptakan sesuatu yang baru.

Acuan dalam Permendikbud Nomor 21 Tahun 2016 jenjang sekolah dasar yaitu tentang kurikulum 2013 pada muatan pelajaran IPA yang memuat capaian kompetensi diantaranya siswa dapat menunjukkan sikap ilmiah meliputi rasa keingintahuan yang tinggi, jujur, logis, kritis, serta disiplin, mengajukan pertanyaan sistematis, melakukan pengamatan objek, dan mencatat hasil dari pengamatan, dan melaporkan hasil pengamatan alam secara lisan maupun tulisan.

Pembelajaran muatan IPA diharapkan dapat menumbuhkan sikap, pengetahuan serta ketrampilan siswa dengan melalui proses ilmiah. Namun, banyak ditemukan pelaksanaan di dalam pembelajaran yang belum sepenuhnya menerapkan kegiatan belajar yang mampu menumbuhkan tiga ranah yang telah disebutkan dalam kurikulum nasional. Peran guru dalam kegiatan pembelajaran hanya menekankan pada capaian yang kognitif yang bersifat menghafal dengan metode ceramah konvensional sehingga siswa tidak dilibatkan secara aktif dalam pembelajaran sehingga capaian kurikulum belum tercapai dengan optimal.

Diperlukan model pembelajaran dalam proses belajar mengajar, dengan menggunakan model pembelajaran diharapkan tujuan pembelajaran dapat tercapai. Model pembelajaran menurut Joyce, dkk. dalam Trianto (2015:52) merupakan perencanaan yang dapat digunakan untuk menciptakan pola dalam kegiatan mengajar baik secara tatap muka di kelas atau tutorial dan menentukan material atau perangkat pembelajaran.

Pembelajaran yang tidak inovatif dan hanya mengacu pada satu sumber belajar tertentu dapat berpengaruh terhadap cara berpikir siswa dalam mencari solusi dari masalah yang timbul. Pembelajaran yang ideal yaitu pembelajaran yang tidak hanya berpusat pada guru melainkan siswa berusaha mencari dan menggali informasi melalui bimbingan guru. Siswa dituntut terlibat secara aktif dan mandiri dalam kegiatan pembelajaran dengan demikian akan melatih kemampuan berpikir kritis. Berpikir kritis menurut Browne dan Keeley dalam Jhonson (2011:183) yaitu kemampuan berpikir dengan jelas dan imajinatif, menilai bukti, bermain logika, mecari alternatif dari ide konvensional serta memberi jalan di jaman teknologi saat ini. Jhonson (2011:185) mengemukakan tujuan dari berpikir kritis yaitu untuk mencapai pemahaman mendalam. Pemahaman yang membuat siswa mengerti akan maksud dan makna dibalik suatu kejadian. Berpikir kritis memungkinkan siswa mempelajari masalah dengan cara sistematis, menghadapi tantangan, merumusakan pertanyaan, serta merancang solusi. Selain itu didukung pula dengan model pembelajaran yang mendukung tercapainya proses pembelajaran yang aktif dan bermakna.

Berbagai pendekatan melalui model pembelajaran yang dapat dipadukan dengan

Copyright (C2020, JRPD, ISSN 2615 - 1723 (Print), ISSN 2615 - 1766 (Online) 
kurikulum saat ini yaitu kurikulum 2013 dengan menciptakan suasana saat proses pembelajaran yang aktif, menyenangkan dan bermakna menjadi salah satu bagian terpenting dimana dalam Kurikulum 2013 itu sendiri menekankan pada pendekatan saintifik. Tujuan pendekatan saintifik menurut Mawardi (2016:128) diantaranya untuk meningkatkan kemampuan pengetahuan siswa yang berfokus pada kemampuan berpikir tingkat tinggi atau High Order Thinking Skill (HOTS), membangun kemampuan siswa dalam menyelesaikan masalah dengan cara yang sistematis, menciptakan suasana pembelajaran bahwa belajar merupakan suatu kebutuhan bagi siswa, melatih siswa mengkomunikasikan ide dalam karya ilmiah, serta untuk mengembangkan karakter siswa dan memperoleh hasil belajar yang tinggi.

Model pembelajaran tidak dapat dipisahkan dari kegiatan pembelajaran. Pembelajaran pada kurikulum 2013 jika berdasarkan Permendikbud Nomor 103 Tahun 2004 bahwa implementasi kurikulum 2013 disarankan menggunakan pendekatan saintifik seperti model pembelajaran inquiry based learning, discovery learning, project based learning, dan problem based learning. Pembelajaran dalam kurikulum 2013 dengan menggunakan pendekatan saintifik agar siswa secara aktif membangun konsep pengetahuan serta proses belajarnya sendiri dengan cara sistematis. Sehingga diperlukan model pembelajaran yang dapat membantu siswa dalam membangun pengetahuan serta menemukan pemecahan dari masalah. Terdapat model pembelajaran yang berpotensi dalam mendorong siswa untuk mencari tahu informasi dari sumber melalui pengamatan mandiri, pemecahan masalah serta penekanan pada sudent centered. Model pembelajaran yang lebih baik diterapkan pada muatan pelajaran IPA yaitu discovery learning. Model discovery learning akan lebih baik jika diterapkan dalam muatan IPA di SD karena model tersebut sejalan dengan hakikat muatan IPA dan tujuan dari pendekatan saintifik.

Model discovery learning menurut Sani (2015:221) merupakan pembelajaran kognitif dimana guru dituntut untuk lebih kreatif dalam menciptakan kegiatan belajar yang dapat membuat siswa secara aktif menemukan pengetahuannya sendiri. Karakteristik model discovery learning Hosnan (2014:284) salah satunya yaitu mengajak siswa untuk mengeksplorasi serta memecahkan masalah secara sistematis dimulai dengan stimulasi, identifikasi masalah, pengumpulan data, pengolahan data, verivikasi atau pembuktian hingga menarik generalisasi atau menarik kesimpulan. Keunggulan dari model discovery learning Kurniasih (2014:64) yaitu melatih siswa belajar berpikir kritis untuk menemukan penemuan melalui pengetahuannya sendiri. Pembelajaran menggunakan model pembelajaran discovery learning merupakan metode yang mengatur kegiatan belajar siswa dengan melibatkan proses mental yaitu siswa mampu mengamati, mencerna, mengerti, menggolongkan, membuat dugaan, mengukur dan menarik kesimpulan sehingga siswa memperoleh pengetahuan yang tidak diketahui sebelumnya dengan cara menemukannya sendiri. Melalui tahapan dalam model discovery learning tersebut, siswa mampu bekerja dan berpikir secara sistematis dengan langkah-langkah ilmiah, secara aktif dan mandiri menemukan hal baru serta meningkatkan kemampuan berpikir kritis siswa. Mengingat kemampuan siswa dalam berpikir kritis sangat diperlukan dalam kegiatan pembelajaran maupun dalam kehidupan sehari-hari.

Penelitian terkait model discovery learning beberapa hasil penelitian menunjukkan bahwa model tersebut dapat meningkatkan kemampuan berpikir kritis siswa. Seperti yang dilakukan oleh Khofiyah (2019:61) terkait dengan model discovery learning berbantuan media benda nyata pada

Copyright (C2020, JRPD, ISSN 2615 - 1723 (Print), ISSN 2615 - 1766 (Online) 


\section{Jurnal Riset Pendidikan Dasar, 03 (1), April 2020 (34-40)}

Yulita Dwi Aryani, Wasitohad

muatan IPA mampu meningkatkan kemampuan berpikir kritis siswa dan pemahaman konsep IPA.

Penelitian menggunakan model discovery learning yaitu dilakukan oleh Rahmatika Eviana, dkk (2016:97) dalam penelitian tersebut terdapat perbedaan signifikan antara kelas yang menggunakan model discovery learning berbantuan dengan $\mathrm{CD}$ interaktif dibandingkan dengan penggunaan model pembelajaran konvensional dan terdapat peningkatan aktivitas siswa yang menggunakan model pembelajaran tersebut pada muatan pelajaran IPS.

Penelitian oleh Purwanti dan Suryani (2018) terkait penerapan model discovery learning berbantuan dengan media powtoon menunjukkan bahwa ada perbedaan kemampuan berpikir kritis siswa dan adanya peningkatan motivasi pada kelas eksperimen menggunakan model discovery learning dibandingkan pada kelas kontrol. Dapat disimpulkan bahwa model discovery learning memiliki pengaruh dalam meningkatkan kemampuan berpikir kritis siswa.

\section{METODE}

Jenis penelitian yang digunakan adalah penelitian eksperimen, menurut Sugiyono (2011:107) pengertian penelitian eksperimen yaitu metode penelitian yang digunakan untuk mencari pengaruh perlakuan tertentu terhadap yang lain dalam kondisi terkendalikan. Penelitian ini menggunakan desain penelitian eksperimental-semu (Quasi Experimental Design) karena kelompok kontrol penelitian ini tidak sepenuhnya mengontrol variabel-variabel luar yang mempengaruhi pelaksanaan eksperimen. Menurut Sugiyono (2011:114) desain quasi ini memiliki kelompok kontrol, namun tidak dapat berfungsi sepenuhnya untuk mengontrol variabel-variabel luar yang mempengaruhi pelaksanaan eksperimen.
Model discovery learning merupakan variabel bebas dalam penelitian ini dan variabel terikat penelitian ini yaitu kemampuan berpikir kritis siswa. Penelitian dilaksanakan di SD Negeri Mangunsari 01 Salatiga dan SD Negeri Mangunsari 05 Salatiga Kecamatan Sidomukti Kota Salatiga. Sampel dalam penelitian ini menggunakan teknik teknik sampling purposive, dimana menurut Sugiyono (2011:124) teknik ini merupakan penentuan sampel dengan pertimbangan tertentu. Sekolah yang dijadikan penelitian merupakan sekolah dengan gugus yang sama. Untuk mengetahui homogenitas dari sampel penelitian, dapat ditunjukkan dengan hasil uji homogenitas pre test maupun post test dari kelas eksperimen dan kelas kontrol yang diperoleh selama kegiatan penelitian.

Berikut merupakan hasil uji homogenitas:

Tabel 1 Uji Homogenitas

Based on Mean Levene Statistic df1 df2 Sig.

$\begin{array}{lllll}\text { Pre test } & 0,058 & 1 & 59 & 0,811 \\ \text { Post test } & 0,000 & 1 & 59 & 0,985\end{array}$

Berdasarkan tabel di atas, bahwa hasil uji homogentitas Lavene Statistic dengan Based on Mean atau berdasarkan rata-rata. Homogenitas data dapat diketahui dari nilai signifikasi kelas pre test yaitu 0,811 dan nilai signifikasi kelas post test yaitu 0,985 dimana nilai tersebut $>0,05$ (lebih dari) sehingga dapat disimpulkan bahwa kelas eksperimen memiliki homogenitas atau variansi yang sama.

Teknik pengumpulan data dalam penelitian ini yaitu tes dan nontes. Tes yang digunakan yaitu pre test dan post test dalam bentuk soal uraian untuk mengetahui kemampuan berpikir kritis siswa sebelum dilakukan perlakuan model dan sesudah perlakuan model. Teknik nontes pada penelitian yaitu menggunakan metode observasi terkait kelas yang akan dijadikan obyek penelitian, melakukan wawancara tidak terstruktur dengan kepala sekolah dan guru

Copyright $@ 2020$, JRPD, ISSN 2615 - 1723 (Print), ISSN 2615 - 1766 (Online) 
kelas serta dokumentasi penelitian. Teknik analisis data yaitu analisis uji instrumen meliputi uji validitas dan uji reliabilitas sedangkan analisis statistik meliputi uji normalitas data, uji homogenitas, uji $\mathrm{T}$ serta uji hipotesis.

\section{HASIL DAN PEMBAHASAN}

Obyek penelitian ini yaitu kemampuan berpikir kritis siswa SD pada muatan IPA dengan materi gaya. Hasil pre test dan post test kelas eksperimen maupun kelas kontrol secara keseluruhan mengalami peningkatan dalam kemampuan berpikir kritis. Berikut merupakan tabel hasil kemampuan berpikir kritis pre test dan post test pada kelas eksperimen dan kelas kontrol

Tabel 2 Hasil Kemampuan Berpikir Kritis Siswa

\begin{tabular}{cccccccc}
\hline \multirow{2}{*}{ Kelas } & N & $\begin{array}{c}\text { Skor } \\
\text { Ideal }\end{array}$ & $\begin{array}{c}\text { Skor } \\
\text { Min }\end{array}$ & $\begin{array}{c}\text { Skor } \\
\text { Max }\end{array}$ & $\begin{array}{c}\text { Rata- } \\
\text { rata }\end{array}$ & $\begin{array}{c}\text { Presentase } \\
\text { tost }\end{array}$ \\
\hline \multirow{2}{*}{ Post test } & $\begin{array}{c}\text { Kelas } \\
\text { Eksperimen }\end{array}$ & 27 & 100 & 55 & 84 & 67,41 & $67 \%$ \\
\cline { 2 - 8 } & Kelas Kontrol & 34 & 100 & 50 & 83 & 64,94 & $65 \%$ \\
\cline { 2 - 8 } & $\begin{array}{c}\text { Kelas } \\
\text { Eksperimen }\end{array}$ & 27 & 100 & 72 & 98 & 85,85 & $86 \%$ \\
\hline
\end{tabular}

Variabel dependen dalam penelitian ini yaitu kemampuan berpikir kritis siswa terhadap muatan pelajaran IPA. Keseluruhan kemampuan berpikir kritis siswa pada kelas eksperimen maupun kelas kontrol dapat meningkat. Rata-rata Teknik pengolahan data hasil kemampuan berpikir kritis siswa menggunakan program SPSS versi 20.0. Kemampuan berpikir kritis siswa diperoleh melalui pre test dan post test.

Berdasarkan tabel hasil kemampuan berpikir kritis siswa rata-rata skor pre test kemampuan berpikir kritis siswa kelas eksperimen yaitu 67,41 dengan skor minimal yaitu 55 dan skor tertinggi yaitu 84 . Adanya peningkatan signifikan pada rata-rata skor kemampuan berpikir kritis siswa setelah diberikan perlakuan model discovery learning yaitu 85,85 dengan skor minimal yaitu 72 dan skor maksimal yaitu 98 sedangkan pada kelas kontrol rata-rata skor pre test kemampuan berpikir kritis siswa yaitu 64,94 dengan skor minimal yaitu 50 dan skor maksimal yaitu 83dan rata-rata skor post test kelas kontrol meningkat setelah diberi perlakuan model PBL (Problem Based Learning) yaitu menjadi 82,88 dengan skor minimal yaitu 50 dan skor maksimal yaitu 96. Rata-rata skor kelas ekperimen menggunakan model discovery learning lebih tinggi dibandingkan dengan kelas kontrol yang menggunakan model PBL(Problem Based Learning). Dari hasil dari pre test dan post test dikomparasikan antara hasil pengukuran kemampuan berpikir kritis pada kelas eksperimen dan kelas kontrol. Berikut merupakan hasil komparasi kemampuan berpikir kritis dari kelas eksperimen dan kelas kontrol.

Tabel 3 Komparasi Hasil Kemampuan Berpikir Kritis Siswa

\begin{tabular}{cccc}
\hline $\begin{array}{c}\text { Tahap } \\
\text { Pengukuran }\end{array}$ & \multicolumn{2}{c}{ Rata-rata Skor Kelompok } & \multirow{2}{*}{ Selisih } \\
\cline { 2 - 3 } & Eksperimen & Kontrol & \\
\hline Pre test & $67 \%$ & $65 \%$ & $2 \%$ \\
\hline Post test & $86 \%$ & $83 \%$ & $3 \%$ \\
\hline
\end{tabular}

Berdasarkan tabel di atas, menujukkan bahwa hasil komparasi rata-rata nilai pre test sebelum mendapat perlakuan dengan model discovery learning dan PBL(problem based learning) yaitu $2 \%$ dan terdapat perbedaan rata-rata nilai post test setelah mendapat perlakuan model discovery learning dan PBL(problem based learning) yaitu 3\%. Dapat disimpulkan bahwa terdapat peningkatan baik dikelas eksperimen maupun kelas kontrol setelah diberikan perlakuan Copyright (C2020, JRPD, ISSN 2615 - 1723 (Print), ISSN 2615 - 1766 (Online) 
masing-masing model dengan hasil komparasi hasil kemampuan berpikir kritis siswa pada kelas eksperimen lebih tinggi dibandingkan dengan kelas kontrol.

Berdasarkan uji normalitas diperoleh data pre test pada kelas eksperimen yaitu 0,055 dan data post test yaitu 0,934. Dapat dinyatakan bahwa nilai probabilitas pada kelas eksperimen $>0,05$ (lebih dari) sehingga data berdistribusi normal. Sedangkan uji normalitas pre test pada kelas kontrol yaitu 0,282 dan post test yaitu

Tabel 4 Hasil Uji Hipotesis Atau Uji-T
0,183. Dapat dinyatakan bahwa nilai probabilitas pada kelas eksperimen dan kelas kontrol > 0,05 (lebih dari) sehingga data berdistribusi normal.

Uji homogenitas diperoleh data pre test kelas eksperimen dan kelas kontrol yaitu 0,811 dan post test kelas eksperimen dan kelas kontrol yaitu 0,985 . Dapat dinyatakan bahwa nilai probabilitas $<0,05$ (lebih dari) sehingga data bersifat homogen.

\begin{tabular}{cccccccc} 
& T & df & $\begin{array}{c}\text { Sig. (2- } \\
\text { tailed) }\end{array}$ & $\begin{array}{c}\text { Perbedaan } \\
\text { rata-rata }\end{array}$ & $\begin{array}{c}\text { Perbedaan } \\
\text { Std. Error }\end{array}$ & \multicolumn{2}{c}{$\begin{array}{c}\text { Perbedaan Jarak } \\
\text { Kepercayaan }\end{array}$} \\
\cline { 5 - 7 } & & & & & Rendah & Tinggi \\
\hline $\begin{array}{c}\text { Kemampua } \\
\text { n berpikir } \\
\text { kritis }\end{array}$ & 9,556 & 59 & 0,000 & 20,911 & 2,188 & 16,532 & 25,289 \\
\hline
\end{tabular}

Berdasarkan hasil uji t diketahui nilai $\mathrm{T}$ yaitu 9,556. Nilai t hitung $>\mathrm{t}$ tabel yaitu 9,556 $>0,339$ sehingga dinyatakan terdapat adanya pengaruh yang siginifikan terhadap rata-rata kemampuan berpikir kritis siswa pada kelas yang eksperimen menggunakan model discovery learning.

Mulyatiningsih (2014:233) berpendapat bahwa model discovery learning digunakan untuk memecahkan masalah secara intensif di bawah pengawasan guru. Pemecahan masalah secara intensif dapat mengasah serta meningkatkan ketrampilan berpikir siswa secara kritis yang menurut Jhonson (2011:185) tujuan dari berpikir kritis yaitu untuk mencapai pemahaman mendalam, memungkinkan siswa mempelajari masalah secara sistematis, menghadapi tantangan, merumuskan pertanyaan serta merancang solusi dari permasalahan.

Peningkatan kemampuan berpikir kritis siswa pada muatan IPA SD sejalan dengan penelitian yang telah dilakukan oleh Rahmatika (2016:97) bahwa model discovery learning berbantuan CD Interaktif memiliki pengaruh terhadap kemampuan berpikir kritis pada muatan pelajaran IPS serta peningkatan aktivitas belajar pada kelas ekseprimen lebih tinggi disbanding dengan kelas kontrol yaitu pada pertemuan pertemuan $64 \%$, pertemuan kedua $91 \%$, dan pertemuan ketiga 94\%. Didukung pula penelitian yang dilakukan oleh Khofiyah (2019:61) bahwa model discovery learning berbantuan dengan media nyata berpengaruh dengan kemampuan berpikir kritis siswa dan pemahaman konsep IPA. Ditunjukkan dengan rata-rata hasil aktivitas pembelajaran kelas eksperimen yaitu 81,5 dan kelas kontrol 77,8 sehingga rata-rata kelas eksperimen lebih tinggi dibandingkan dengan kelas kontrol. Hasil uji t terhadap kemampuan berpikir kritis siswa yaitu 2,718. Perbandingan nilai t hitung $>\mathrm{t}$ tabel yaitu 2,718>2,012 dapat disimpulkan bahwa terdapat perbedaan signifikan terhadap kemampuan berpikir kritis siswa. Penelitian terkait model discovery learning berbantuan dengan media Powtoon terhadap kemampuan berpikir kritis siswa dilakukan oleh Purwanti dan Suryani (2018) menyatakan bahwa terdapat pengaruh motivasi dan kemampuan berpikir kritis pada kelas eksperimen lebih tinggi dibandingkan kelas kontrol yaitu 91,9 > 91,7. 


\section{SIMPULAN}

Simpulan penelitian ini yaitu terdapat pengaruh yang signifikan terhadap kemampuan berpikir kritis siswa melalui penerapan model discovery learning. Hal tersebut ditunjukkan bahwa kemampuan berpikir kritis siswa kelas IV SD pada muatan IPA lebih tinggi dibandingkan dengan siswa yang diberikan perlakuan model lain yaitu model PBL (problem based learning).

Saran peneliti yang pertama bagi pendidik atau guru melalui penelitian ini apabila hendak menerapkan model discovery learning akan lebih baik jika merencanakan pembelajaran dengan persiapan dengan sebaikbaiknya. Pentingnya untuk mengalokasikan waktu belajar yang lebih panjang karena pembelajaran dengan menerapkan model discovery learning lebih banyak melibatkan siswa dalam kegiatan pembelajaran seperti halnya melakukan pengamatan, diskusi kelompok, pembuktian dan menyajikan hasil pengamatan. Dari hasil penelitian menunjukkan terdapat pengaruh yang signifikan dari penerapan model discovery learning terhadap kemampuan berpikir kritis siswa, disarankan bagi guru untuk mengaplikasikan model tersebut dalam kegiatan pembelajaran di kelas.

Saran peneliti yang kedua, bagi peneliti lain diharapkan melalui penelitian ini dapat menjadi salah satu referensi namun apabila hendak menerapkan model pembelajaran yang sama akan lebih baik menggunakan media pembelajaran sehingga lebih inovatif.

\section{DAFTAR PUSTAKA}

Hosnan. (2014). Pendekatan Saintifik dan Kontekstual dalam Pembelajaran Abad 21. Bogor: Ghalia Indonesia.

Jhonson, Elaine B. (2011). Contextual Teaching and Learning. Bandung: Mizan Media Utama.

Khofiyah, N.H. (2019). Pengaruh Model Discovery Learning Berbantuan Media Benda Nyata Terhadap Kemampuan Berpikir Kritis dan Pemahaman Konsep IPA.http:/journal.um.ac.id/index.php/jp tpp/arcticle/view.

Kurniasih, I \& Berlin, S. (2014). Sukses Mengimplementasikan Kurikulum 2013. Jakarta:Kata Pena.
Mawardi, M., \& Mariati, M. (2016). Komparasi Model Pembelajaran Discovery Learning dan Problem Solving Ditinjau Dari Hasil Belajar IPA Pada Siswa Kelas 3 SD di Gugus Diponegoro - Tengaran. Scholaria: Jurnal Pendidikan Dan Kebudayaan, $6 \quad$ (1), 127142.https://doi.org/https://doi.org/10.2 4246/i.scholaria.2016.v6.i1.p127-142.

Peraturan Menteri Pendidikan dan Kebudayaan Nomor 21 Tahun 2016 tentang Standar Isi Pendidikan Dasar dan Menengah.

Peraturan Menteri Pendidikan dan Kebudayaan Nomor 103 Tahun 2004 tentang Implementasi Kurikulum 2013.

Purwanti, K.Y \& Suryani. (2018) .Pengaruh Discovery Learning Dengan Pendekatan Scientific Berbantuan Powtoon Terhadap Motivasi dan Kemampuan Berpikir Kritis. Jurnal unw. http://Jurnal.unw.ac.id:1254/index.php /janacitta/article/view

Rahmatika, E. (2016). Pengaruh Model Discovery Learning Berbantu CD Interaktif Terhadap Kemampuan Berpikir Kritis Dan Aktivitas Siswa. Journal of Primary Education.

http:/journal.unnes.ac.id/sju/index.php/ jpe/article/view.

Sani, R.A. (2013) Inovasi Pembelajaran. Jakarta: Bumi Aksara

Sugiyono. (2011) Metode Penelitian Pendidikan Pendekatan Kuantitatif, Kualitatif dan $R \& D$. Bandung:Alfabeta.

Trianto. (2015) . Mendesain Model Pembelajaran Inovatif, Progresif, Dan Kontekstual. Jakarta: Prenadamedia Group. 